УДК 35.072.2(4:477)(043.2)

DOI: $10.34132 /$ pard2021.13.11

\title{
ЕФЕКТИВНІСТЬ РЕАЛІЗАЦІЇ ЄВРОПЕЙСЬКИХ ПРОГРАМ ПІДТРИМКИ РЕФОРМУВАННЯ ПУБЛІЧНОГО УПРАВЛІННЯ В УКРАЇНІ
}

Хаджнирадєва $\boldsymbol{C}$. $\boldsymbol{K}$., д-р наук 3 держ. упр., професор, Українська школа урядування, заступник директора - керівник Центру оцінювання кандидатів на посади державної служби, м. Київ, Україна.

Шевцова О. В., магістр, Київський національний університет імені Тараса Шевченка м. Київ, Україна.

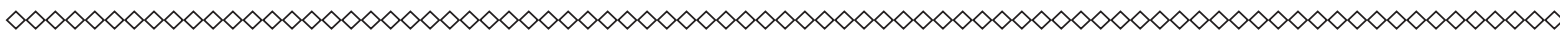

У статті обтрунтовується ефективності реалізаиії європейських програм підтримки реформування публічного управління в Україні. Автором застосовано метод SWOT-аналізу, який дозволив вивчити дану тематику з позииії сильних та слабких сторін, можливостей та загроз. Перевагою даного інструменту є визначення та пріоритизачія стратегічних питань $у$ вищезазначеній сфері.

Встановлено, щзо сильними сторонами європейських програм підтримки реформування публічного управління в Украӥні $є$ : посилення проактивності Уряду України; запровадження правових та стратегічних рамок; посилення ролі лідерства та командної роботи; цифрровізація та координація міжінституційних взаємозв'язків. Слабкі сторони - відсутність в Украӥні єдиної бази надання підтримки донорами; неузгодженість назв програм; відсутність ключових дефініцій у профільному законодавстві; невиконання усіх зазначених індикаторів програм; відсутність інформації у реєстрі програм щзодо акту Кабінету Міністрів України про виконання індикаторів та досягнення очікуваних результатів (у разі прийняття).

За результатами проведеного SWOT-аналізу використання європейських програм підтримки реформування публічного 
управління в Украӥні ми пропонуємо такі практичні рекомендачії щуодо підвищення ефективності їх використання: а) нормативно закріпити у профільному законодавстві дефінічії «публічна служба» та «публічне управління», замінити термінологію «реформування публічного управління» на «європеї̈зачію публічного управління»; б) запровадити контентний аудит при підготовиі до запиту про надання міжнародної технічної допомоги з метою уникнення дублювання проєктів/програм, або їх компонентів; в) створити єдиний реєстр міжнародної технічної допомоги міжнародних партнерів України, а існуючі проєкти об'єднати у програми за секторами; г) розробити крос-секторальну матрицю впливу від інших проєктів/програм, які роблять внесок у реформування публічного управління в Україні; д) розробити трирівневу систему підтримки реалізації європейських програм підтримки реформування публічного управління в Україні, щяо базуватиметься на взаємодіі та інтероперабельності на національному, регіональному та локальному рівнях; е) визначати лише ті індикатори прогресу імплементації програм, які реально досягти, отже, покращити систему розрахунку ризиків; Запровадити індекс задоволеності громадян від реформи публічного управління в Україні, як користувачів сервісної держави.

Перспективу подальших досліджень вбачаємо у вивчення проєктних компетентностей публічних службовців та їхньої готовності до управління ризиками міжнародних проєктів $i$ програм.

Ключові слова: Угода про асоціацію, СС, публічне управління, реформування, проєкт.

Постановка проблеми у загальному вигляді. У світлі євроінтеграційного курсу України, закріпленого в Основному законі, ключовим на трансформаційному шляху європеїзації нашої держави є імплементація Угоди про асоціацію між Україною та Європейським Союзом, що передбачає політичну асоціацію та економічну інтеграцію України з СС. У період з 2007 по 2013 рр. 
ЄС виділив 1,0056 млрд. євро на двосторонню допомогу Україні, де серед пріоритетів було визначено підтримку демократичного розвитку та належного державного управління [6, с.3].

Практичним інструментом для належної імплементації Угоди про асоціацію $є$ Порядок денний асоціації $\epsilon$, що представляє собою основний механізм моніторингу та оцінювання прогресу України у виконанні Угоди про асоціацію між Україною та СС, а також моніторингу та оцінювання досягнень всіх цілей політичної асоціації та економічної інтеграції в цілому, особливо, що стосується досягнень України у гарантуванні поваги до спільних цінностей та прогресу у досягненні відповідності з СС у політичній, економічній та правовій сферах. Документ містить десять короткострокових пріоритетів, які є першочерговими для України, серед яких вказано реформу у сфері державного управління.

Враховуючи беззаперечну важливість питання реформи державного управління для виконання Угоди про асоціацію між Україною та Свропейським Союзом, а також готовність та безупинну підтримку європейських партнерів в даному напрямку, надзвичайно актуальним є дослідження використання європейських програм підтримки реформування публічного управління в Україні, 3 метою підвищення їх ефективності та оптимізації механізмів реалізації.

Водночас для формування порівняльних переваг, викликів та ризиків та з метою забезпечення всебічності дослідження, варто провести SWOT-аналіз, який дозволить вивчити дану тематику 3 позиції сильних та слабких сторін, можливостей та загроз. Перевага даного інструменту полягає в тому, що він передбачає аналіз внутрішніх та зовнішніх факторів, а також допомагає визначити контекст, в якому критичним кроком $є$ визначення та пріоритизація стратегічних питань [17, с.3].

Аналіз останніх досліджень і публікацій. Варто зауважити, що системних досліджень в цій сфері не проводилося, однак як вітчизняні, так і зарубіжні вчені та експерти відмічають у своїх публікаціях актуальність цього питання [18; 20 та ін.]. Триває доопрацювання проекту Стратегії реформування державного 
управління на період до 2025 року. Наразі готується бюджетна декларація на наступні три роки, а також оновлена Стратегія реформування державного управління до 2025 року, в межах якої має принципово бути врегульовано питання прозорості та справедливості в оплаті праці державних службовців.

На нашу думку, проактивність Уряду прямо визначає продовження надання бюджетної підтримки зі сторони європейських партнерів. В українських документах мова йде про програму реформування державного управління, в документах Європейської Комісії уживається термін проєкт та реформа публічної адміністрації, з чого не цілком зрозуміло, що саме реформується. Така термінологічна неузгодженість вимагає деталізації цих понять, а також вивчення рівня ефективності європейських програм підтримки реформування публічного управління в Україні.

Формулювання цілей статті (постановка завдання). Мета статті - презентувати та науково обгрунтувати ефективність європейських програм підтримки реформування публічного управління в Україні із застосуванням методу SWOT-аналіз.

Виклад основного матеріалу дослідження. Для формування порівняльних переваг, викликів та ризиків та з метою забезпечення всебічності такого дослідження, ми використали метод SWOTаналізу. Опишемо основний зміст отриманих результатів.

1. Сильні сторони використання європейських програм підтримки реформування публічного управління в Україні.

На прохання Уряду України та за фінансової підтримки DFID (Міністерства міжнародного розвитку Сполученого Королівства Великої Британії) i SIDA (Швецького агентства 3 міжнародного розвитку), а також за згодою Свропейської Комісії, на початку 2006 року SIGMA провела оцінку державного управління в Україні згідно з якою одним з пріоритетів було визначено - прийняти новий «Закон про державну службу» - посилити професійність [14, с.10], після чого у 2011 році отримано коментарі програми SIGMA щодо законопроекту України «Про державну службу» [16], а в 2015 році прийнято новий Закон України «Про державну службу». 
Серед значних досягнень у формуванні правових рамок 3 акцентом на стратегування варто виділити прийняття Стратегії реформування державного управління України на період до 2021 року в 2016 році, то подальше закріплення змін в редакції 2018 року. У грудні 2016 року було підписано фінансову угоду між Урядом України та Європейською Комісією, що передбачає підтримку України в реалізації Стратегії реформування державного управління на період до 2021 року в межах програми СС «Підтримка комплексної реформи державного управління в Україні».

Крім того, варто виокремити схвалення розпорядженням Кабінету Міністрів України від 27 грудня 2017 р. № 1013 Концепції оптимізації системи центральних органів виконавчої влади, схваленням розпорядженням Кабінету Міністрів України від 27 травня 2020 р. № 622 Концепції реформування системи оплати праці державних службовців,а також схвалення розпорядженням Кабінету Міністрів України від 21 липня 2021 р. № 831-р Стратегії реформування державного управління України на 2022-2025 роки.

Створення належних правових та стратегічних рамок $\epsilon$ безумно сильною стороною використання європейських програм підтримки реформування публічного управління в Україні.

На прояв політичної волі та 3 метою визначення лідера Прем'єр-міністр України визначив Міністра Кабінету Міністрів України відповідальним за координацію реформування державного управління. У складі Секретаріату Кабінету Міністрів України утворено самостійний структурний підрозділ з питань реформування державного управління, який забезпечує супроводження реформи та підтримку діяльності політичного керівництва i координації реформи [11].

Крім того, було створено Координаційну раду 3 питань реформування державного управління, яка $\epsilon$ тимчасовим консультативно-дорадчим органом Кабінету Міністрів України, утвореним з метою забезпечення координації заходів з розроблення проектів та реалізації Стратегії реформування державного управління на період до 2021 року та Стратегії реформування системи управління державними фінансами на 2017-2020 роки [7]. 
Отже, до сильних сторін можна віднести визначення політичного лідера, та командоутворення для реалізації змін.

У рамках реформи створено Єдиний державний веб-портал електронних послуг, систему електронної взаємодії державних електронних інформаційних ресурсів «Трембіта», а також значна кількість адміністративних послуг доступна в режимі онлайн, наприклад, «єМалятко», що дозволяє виокремити таку сильну сторону, як цифровізація.

У 2020 році за ініціативою Уряду України, було створено Директорат координації міжнародної технічної допомоги при Секретаріаті Кабінету Міністрів України, що відкриває можливості для більш координованої взаємодії між Урядом України та партнерами 3 розвитку. За результатами консультацій між представниками Уряду і партнерами з розвитку було прийняте рішення удосконалити існуючу систему координації міжнародної технічної допомоги для визначення i впровадження ключових пріоритетів розвитку України. Система координації складається із трьох взаємозалежних рівнів:

1) Форум «Партнерство 3 розвитку» - створений для політичного діалогу високого рівня щодо стратегічних питань реалізації національних реформ.

2) Стратегічна платформа - створена для стратегічної координації міжнародної технічної допомоги (МТД) з пріоритетами національних реформ із урахуванням Цілей сталого розвитку та Угоди про асоціацію між Україною та СС.

3) Секторальні робочі групи (СРГ) створені для проведення регулярного діалогу та координації між центральними органами виконавчої влади і партнерами 3 розвитку за відповідними напрямами державної політики та секторальними реформами [3].

Таким чином, координація $\epsilon$ важливим компонентом сильних сторін використання європейських програм підтримки реформування публічного управління в Україні.

2. Слабкі сторони імплементації європейських програм підтримки реформування публічного управління в Україні.

На вебсайті Кабінету Міністрів України є реєстр програм секторальної бюджетної підтримки СС, в якому вказано дві програми 
[10], а окремо опубліковано перелік проєктів технічної допомоги Україні, зареєстрованих у Секретаріаті Кабінету Міністрів України [5], що свідчить про відсутність єдиної бази надання підтримки донорами.

Іншою слабкою стороною можна назвати неузгодженість назв програм, простежується повтор. Наприклад, $є$ програма «Децентралізація і реформа публічної адміністрації в Україні», що реалізується в рамках Плану дій Ради Свропи для України [9]. Мовою оригіналу вона звучить «Enhancing decentralisation and public administration reform in Ukraine» [15] - що в українському перекладі перетворилось на «реформу публічної адміністрації». Водночас $\epsilon$ програма фінансування СС «Підтримка комплексного реформування державного управління в Україні» ENI/2016/039-569 (19.12.2016) на основі Угоди між Урядом України та Свропейською Комісією про фінансування програми «Підтримка комплексного реформування державного управління в Україні», Додаткової угоди № 2 до Угоди про фінансування ENI/2016/039-569 «Підтримка комплексного реформування державного управління в Україні», яка мовою оригіналу звучить як «Support to Comprehensive Reform of Public Administration Ukraine». Як бачимо, в обох випадках вжито однакові поняття англійською мовою, які перетворились на абсолютно різні поняття в їхньому українському варіанті. Варто зазначити, що найвдаліший україномовний еквівалент до поняття «public administration» - «публічне управління», а отже, в Україні є дві програми щодо реформування публічного управління.

Крім того, варто наголосити на відсутності дефініції публічної служби у профільному законі, натомість п.1 ст.1 державну службу визначено публічною [1]. На сьогоднішній день дефініцію поняття «публічна служба» надано лише в законодавстві про адміністративне судочинство: це діяльність на державних політичних посадах, у державних колегіальних органах, професійна діяльність суддів, прокурорів, військова служба, альтернативна (невійськова) служба, інша державна служба, патронатна служба в державних органах, служба в органах влади Автономної Республіки Крим, органах місцевого самоврядування [2]. Згадується публічна служба і 
в нещодавно прийнятій Стратегії реформування державного управління України на 2022-2025 роки, але в розумінні державної служби та служби в органах місцевого самоврядування: «Професійна публічна служба та управління персоналом. Метою цього напряму Стратегії $є$ продовження розбудови професійної, доброчесної, політично нейтральної державної служби та служби в органах місцевого самоврядування, діяльність якої спрямована на захист інтересів громадян» [12].

Стратегією реформування державного управління на період до 2021 року передбачалось впровадження інформаційної системи управління людськими ресурсами та нарахування заробітної плати (HRMIS), а індикатором виконання визначено - введення системи в промислову експлуатацію та підключення до неї міністерств та інших ЦОВВ. Цілі повною мірою досягнуто не було, і у Стратегії реформування державного управління України на 2022-2025 роки передбачається продовжити впровадження інтегрованої інформаційної системи управління людськими ресурсами в державних органах (HRMIS), яка дасть змогу проводити оперативний прозорий моніторинг чисельності працівників органів державної влади і фонду оплати праці та в подальшому замінити подібні інформаційні системи в таких органах [12].

Відсутність інформації щодо нормативно-правових актів на виконання програми підтримки реформи публічного управління - в Стратегії реформування державного управління на період до 2021 року згадуються Закон України «Про державне стратегічне планування», подання проекту Закону України «Про адміністративну процедуру» до Верховної Ради України та його супроводження, розроблення та подання Кабміну законопроєкту «Про внесення змін до Законів України «Про центральні органи виконавчої влади та «Про Кабінет Міністрів України» 3 метою удосконалення організації та порядку функціонування Кабміну та ЦОВВ, розроблення та подання Кабміну законопроєкту «Про нормативно-правові акти» 3 метою закріплення єдиних вимог до нормопроєктування та вирішення колізійних питань, розроблення та подання Кабміну законопроєкту «Про публічні консультації», 
розроблення та подання Кабміну законопроєкту «Про внесення змін до деяких законодавчих актів України щодо позбавлення КМУ невластивих повноважень» у документі перелічено багато індикаторів досягнення результатів, проте в реєстрі програм секторальної бюджетної підтримки Європейського Союзу, в програмі «Підтримка комплексного реформування державного управління в Україні» в графі «дата і номер акту Кабінету Міністрів України про виконання індикаторів та досягнення очікуваних результатів (у разі прийняття)» нічого не зазначено [10].

3. Можливості реалізації європейських програм підтримки реформування публічного управління в Україні.

У результаті успішної імплементації фінансової угоди між Урядом України та Європейською Комісією, що передбачає підтримку України в реалізації Стратегії реформування державного управління на період до 2021 рок в межах програми $Є С$ «Підтримка комплексної реформи державного управління в Україні» Уряд України може сподіватись на отримання бюджетної підтримки для виконання Стратегії реформування державного управління України на 2022-2025 роки.

Іншою суттєвою можливістю $\epsilon$ проведення аудиту всіх програм підтримки реформування публічного управління в Україні. Така інтегральна оцінка дасть можливість своєчасно виявити та усунути можливі розриви та перешкоди на шляху до реалізації індикаторів виконання, а також ідентифікувати непокриті або не до кінця покриті секторальні компоненти 3 метою своєчасного усунення прогалин у реформуванні публічного управління, що мають важливе стратегічне значення та включення їх до майбутніх програм підтримки.

Оскільки станом на тепер на сайті Кабінету Міністрів України опубліковані реєстр програм секторальної бюджетної підтримки Європейського Союзу, а також перелік проєктів технічної допомоги Україні, зареєстрованих у Секретаріаті Кабінету Міністрів України, у сукупності це дає потенційне інформаційне наповнення та базу для створення єдиного реєстру міжнародної технічної допомоги Україні за секторами. У зв'язку з великою кількістю проєктів, 
вказаних у переліку Кабінету Міністрів України, потенційно їх можна об'єднати у програми або портфелі для кращого бачення та розуміння покритих ними компонентів 3 метою забезпечення всебічності та уникнення дублювання компонентів у різних проєктах, адже для досягнення єдиного результату проєкти можуть бути облєднані в програму проєктів або ж портфель проєктів для ефективнішого управління, а портфель проєктів, у свою чергу, може включати також програми [8].

Оскільки на меті ставиться побудова в Україні спроможної сервісної та цифрової держави, яка забезпечує захист інтересів громадян на основі європейських стандартів та досвіду [12], важливою $\epsilon$ думка та зворотній зв>язок від громадян щодо ефективності використання підтримки 3 боку європейських партнерів реформи публічного управління в Україні. 3 цією метою можна провести соціологічне опитування. Також можна провести опитування українських та європейських лідерів думки, щоб зрозуміти ставлення до використання європейських програм підтримки реформування публічного управління в Україні.

Для забезпечення транспарентності з метою побудови довіри громадян до реформи публічного управління 3 підтримкою європейських партнерів на цьому шляху можна публікувати звіти за результатами моніторингу імплементації європейських програм підтримки реформування публічного управління в Україні, а також періодично проводити публічні заходи, присвячені висвітленню досягнень у цій царині 3 їх відеотрансляцією, відеозаписом та подальшим викладом на вебсайтах та соціальних мережах 3 метою залучення якомога більшої кількості учасників.

Оскільки сучасні підходи до вироблення публічної політики базуються на залученні усіх стейкхолдерів, залучати активніше громадянське суспільство до процесу підготовки запиту про надання підтримки європейським партнерам.

Крім того, з метою «нікого не залишити осторонь» можна створити трирівневу систему підтримки реалізації європейських програм підтримки реформування публічного управління в Україні, що базуватиметься на взаємодії та інтероперабельності на національному, регіональному та локальному рівнях. 
Стратегія реформування державного управління України на період до 2021 року узгоджувалась 3 положеннями Стратегії сталого розвитку «Україна - 2020», схваленою Указом Президента України від 12 січня 2015 р. № 5, зокрема розділом 3 «Дорожня карта та першочергові пріоритети реалізації Стратегії», в якому однією 3 першочергових реформ визначено реформу державного управління, що має на меті побудову прозорої системи державного управління, створення професійного інституту державної служби, забезпечення iii ефективності. Результатом проведення реформи повинно стати створення ефективної, прозорої, відкритої та гнучкої структури державного управління із застосуванням новітніх інформаційнокомунікативних технологій (електронне урядування) для забезпечення формування і реалізації цілісної державної політики, спрямованої на суспільний сталий розвиток і адекватне реагування на внутрішні та зовнішні виклики [13]. Наразі доречно дослідити взаємозв'язок з цілями сталого розвитку, значення яких закріплено зокрема в Указі Президента України №722/2019 «Про Цілі сталого розвитку України на період до 2030 року».

4. Загрози щодо ефективності використання європейських програм підтримки реформування публічного управління в Україні.

Оскільки політична воля і лідерство є вирішальними факторами для успішного планування та проведення реформи державного управління, реформа $є$ міжгалузевою і проводиться у цілісний та узгоджений спосіб, чого неможливо досягти без політичного лідера 3 достатніми повноваженнями та підтримкою Прем'єр-міністра України, Прем'єр-міністр України визначив Міністра Кабінету Міністрів України відповідальним за координацію реформування державного управління. У зв'язку з цим зміна Уряду України може представляти загрозу ефективності використання європейських програм підтримки реформування публічного управління в Україні.

Іншою загрозою $є$ неповнота реалізації європейських програм підтримки реформування публічного управління в Україні. За попередньою оцінкою, виконання індикаторів програми фінансування $\mathrm{CC}$ «Підтримка комплексного реформування державного управління в Україні» становитиме близько 70 \% [4]. 
Тривалість реформування становить ще одну загрозу інвестиційній привабливості продовження фінансування 3 боку європейських партнерів. Оскільки попередній етап розпочався у 2015 році з прийняття Закону України «Про державну службу», а нещодавно прийнята стратегія діятиме до 2025 року.

Інша суттєва загроза ефективності використання європейських програм підтримки реформування публічного управління в Україні «overlapping» або дублювання проєктів/програм або їх компонентів. До цього може призводити,з одного боку, відсутність контентного аудиту при зверненні за допомогою. Наприклад, Стратегією реформування державного управління України на 2022-2025 роки передбачається прийняття нової редакції Закону України «Про службу в органах місцевого самоврядування», водночас програма Ради Свропи «Децентралізація і реформа публічної адміністрації в Україні» передбачає компонент удосконалення законодавчої бази у сфері місцевого самоврядування відповідно до європейських стандартів та кращих практик, що необхідно врахувати при зверненні до ЄС щодо бюджетної підтримки цієї Стратегії, наміри про що були заявлені Міністром Кабінету Міністрів України.

А 3 іншого боку - відсутність єдиного реєстру та системи, що, в свою чергу, позбавляє можливості бачити матрицю тих крос-секторальних компонентів, що реалізуються за підтримки міжнародних донорів. Наприклад, програма реформування державного управління в Україні містить аспект гендерної рівності. Водночас, в Україні реалізуються численні міжнародні проєкти у даній царині. Наприклад, з 2017 року ООН Жінки реалізує проєкт «Гендерна рівність у центрі реформ, миру та безпеки», який фінансується Швецією. Проєкт спрямований на консолідацію зусиль Уряду, Верховної Ради та громадянського суспільства щодо усунення структурних бар'єрів на шляху до гендерної рівності та дотримання прав жінок 3 метою досягнення трансформаційних результатів у становленні гендерної рівності та розширення прав і можливостей жінок в Україні шляхом гендерного інтегрування в систему державного управління зокрема. Отже, даний проєкт робить внесок та підтримує реформу публічного управління в 
Україні. Побудувавши такі тематичні матриці, ми матимемо повну картину наявної підтримки з боку донорів.

Ще одна загроза - фіксація надання підтримки 3 боку європейських партнерів. Наприклад, міжнародні організації часто співпрацюють з ЦОВВ на основі меморандумів та можуть надавати консультаційну підтримку, чи брати участь у роботі, яка не буде відображена у проєкті або програмі, але може мати велике значення для реформи іє результатом надання підтримки нашими європейськими партнерами отримана від міжнародних партнерів.

Відсутність узгодженості на всіх рівнях та можливості рівного представництва всіх регіонів та громад несе загрозу територіальній інклюзивності використання підтримки європейських партнерів України процесу реформування публічного управління. Наприклад, $\epsilon$ проєкти, які сприяють реформування певних областей/ громад, а по певним областям робота не ведеться.

Нарешті останню, але не менш важливу загрозу щодо ефективності використання європейських програм підтримки реформування публічного управління в Україні, яку ми хотіли б виокремити - це відсутність чіткого нормативного закріплення дефініцій у профільному законодавстві, що може призводити до нормативних та правозастосовчих колізій у майбутньому.

Висновки. Оскільки реформа державного управління має велике значення для імплементації Угоди про асоціацію між Україною та Свропейським Союзом, а європейські партнери невпинно підтримують Україну на цьому шляху, актуальність дослідження використання європейських програм підтримки реформування публічного управління в Україні, 3 метою підвищення їх ефективності та оптимізації механізмів реалізації $\epsilon$ безумною. Встановлено, що сильними сторонами європейських програм підтримки реформування публічного управління в Україні є: посилення проактивності Уряду України; запровадження правових та стратегічних рамок; посилення ролі лідерства та командної роботи; цифровізація та координація міжінституційних взаємозв'язків. Слабкі сторони - відсутність в Україні єдиної бази надання підтримки донорами; неузгодженість назв програм; 
відсутність ключових дефініцій у профільному законодавстві; невиконання усіх зазначених індикаторів програм; відсутність інформації у реєстрі програм щодо акту Кабінету Міністрів України про виконання індикаторів та досягнення очікуваних результатів (у разі прийняття).

Щодо можливостей запровадження європейських програм підтримки реформування публічного управління в Україні слід відмітити такі: бюджетна підтримка з боку європейських партнерів; аудит всіх програм підтримки реформування публічного управління в Україні; створення єдиного реєстру міжнародної технічної допомоги Україні за секторами; соціологічне опитування громадян щодо ефективності використання підтримки з боку європейських партнерів реформи публічного управління в Україні (опитування українських та європейських лідерів думки); створення трирівневої системи підтримки реалізації європейських програм; взаємозв'язок 3 цілями сталого розвитку. До основних загроз належать: зміна Уряду України; неповна реалізація європейських програм підтримки реформування публічного управління в Україні; тривалість реформи; дублювання проєктів/програм або їх компонентів;

За результатами проведеного SWOT-аналізу використання європейських програм підтримки реформування публічного управління в Україні ми пропонуємо такі практичні рекомендації щодо підвищення ефективності їх використання:

- Нормативно закріпити у профільному законодавстві дефініції «публічна служба» та «публічне управління», замінити термінологію «реформування публічного управління» на «європеіїзацію публічного управління».

- Запровадити контентний аудит при підготовці до запиту про надання міжнародної технічної допомоги з метою уникнення дублювання проєктів/програм, або їх компонентів.

- Створити єдиний реєстр міжнародної технічної допомоги міжнародних партнерів України, а існуючі проєкти об'єднати у програми за секторами.

- Розробити крос-секторальну матрицю впливу від інших проєктів/програм, які роблять внесок у реформування публічного управління в Україні. 
- Розробити трирівневу систему підтримки реалізації європейських програм підтримки реформування публічного управління в Україні, що базуватиметься на взаємодії та інтероперабельності на національному, регіональному та локальному рівнях.

- Визначати лише ті індикатори прогресу імплементації програм, які реально досягти, отже, покращити систему розрахунку ризиків.

- Розробити KPI та індикатори ефективності використання європейських програм підтримки реформування публічного управління в Україні.

- Запровадити індекс задоволеності публічних службовців від реформи публічного управління в Україні.

- Запровадити індекс задоволеності громадян від реформи публічного управління в Україні, як користувачів сервісної держави.

Перспективу подальших досліджень вбачаємо у вивчення проєктних компетентностей публічних службовців та їхньої готовності до управління ризиками міжнародних проєктів і програм.

\section{Стаття надійшла до редакції: 22.06.21}

\section{EFFICIENCY OF IMPLEMENTATION EUROPEAN REFORM SUPPORT PROGRAMS PUBLIC GOVERNANCE IN UKRAINE}

Svitlana Khadzhyradieva, doctor of Science in Public Administration, Professor, Ukrainian School of Government, Kyiv, Ukraine.

Jelena Shevtsova, magistr department of Public Policy Taras Shevchenko National University of Kyiv, Ukraine.

The article substantiates the effectiveness of the implementation of European programs to support public administration reform in Ukraine. 
The author used the method of SWOT-analysis, which allowed to study this topic from the standpoint of strengths and weaknesses, opportunities and threats. The advantage of this tool is the identification and prioritization of strategic issues in the above area.

It is established that the strengths of European programs to support public administration reform in Ukraine are: strengthening the proactivity of the Government of Ukraine; introduction of legal and strategic framework; strengthening the role of leadership and teamwork; digitization and coordination of inter-institutional relations. Weaknesses - lack of a single donor support base in Ukraine; inconsistency of program names; lack of key definitions in the relevant legislation; noncompliance with all these program indicators; lack of information in the register of programs on the act of the Cabinet of Ministers of Ukraine on the implementation of indicators and the achievement of expected results (if adopted).

Regarding the possibilities of implementing European programs to support public administration reform in Ukraine, the following should be noted: budget support from European partners; audit of all programs to support public administration reform in Ukraine; creation of a single register of international technical assistance to Ukraine by sectors; sociological survey of citizens on the effectiveness of the use of support from European partners in public administration reform in Ukraine (survey of Ukrainian and European opinion leaders); creation of a three-tier system to support the implementation of European programs; relationship to sustainable development goals. The main threats include: change of the Government of Ukraine; incomplete implementation of European programs to support public administration reform in Ukraine; duration of the reform; duplication of projects / programs or their components;

Based on the results of the SWOT-analysis of the use of European programs to support public administration reform in Ukraine, we offer the following practical recommendations for improving the efficiency of their use: a) "On the» Europeanization of public administration «; b) introduce a content audit in preparation for a request for international technical assistance in order to avoid duplication of projects / programs 
or their components; c) create a single register of international technical assistance of Ukraine's international partners, and integrate existing projects into programs by sector; d) develop a cross-sectoral impact matrix from other projects / programs that contribute to public administration reform in Ukraine; e) develop a three-tier system to support the implementation of European programs to support public administration reform in Ukraine, based on interaction and interoperability at the national, regional and local levels; f) identify only those indicators of progress in the implementation of programs that can actually be achieved, and therefore improve the risk calculation system; Introduce an index of citizens' satisfaction with public administration reform in Ukraine as users of the service state.

We see the prospect of further research in the study of project competencies of public servants and their willingness to manage the risks of international projects and programs.

Key words: Association Agreement, EU, public administration, reform, project.

\section{Received: 22.06.21}

\section{References}

1. Zakon Ukrainy Pro derzhavnu sluzhbu [Law of Ukraine On Civil Service]. (n.d.). zakon.rada.gov.ua. Retrieved from https://zakon.rada.gov.ua/ laws/show/889-19\#Text [in Ukrainian].

2. Kodeks administratyvnoho sudochynstva Ukrainy [Code of Administrative Procedure of Ukraine]. (n.d.). zakon.rada.gov.ua. Retrieved from https://zakon.rada.gov.ua/laws/show/2747-15\#Text [in Ukrainian].

3. Koordynatsiia mizhnarodnoi tekhnichnoi dopomohy [Coordination of international technical assistance. (n.d.). www.kmu.gov.ua. Retrieved from https://www.kmu.gov.ua/diyalnist/mizhnarodna-dopomoga/coordination [in Ukrainian].

4. Oleh Nemchinov: YeS pidtrymuie Ukrainu u vprovadzhenni reformy derzhupravlinnia [Oleg Nemchinov: EU supports Ukraine in implementing 
public administration reform]. www.kmu.gov.ua. Retrieved from https://www. kmu.gov.ua/news/oleg-nemchinov-yes-pidtrimuye-ukrayinu-u-vprovadzhenni-reformi-derzhupravlinnya [in Ukrainian].

5. Perelik proiektiv tekhnichnoi dopomohy Ukraini, zareiestrovanykh u Sekretariati Kabinetu Ministriv Ukrainy [List of technical assistance projects for Ukraine registered with the Secretariat of the Cabinet of Ministers of Ukraine]. (n.d.). drive.google.com. Retrieved from https://drive.google.com/ file/d/1zYNaoR8cJBqzVXtALBP7hHpAvmoeBbz9/view [in Ukrainian].

6. Poriadok dennyi asotsiatsii mizh Ukrainoiu ta YeS dlia pidhotovky ta spryiannia implementatsii Uhody pro asotsiatsiiu [Agenda of the Association between Ukraine and the EU for the preparation and facilitation of the implementation of the Association Agreement]. (n.d.). www.kmu.gov.ua. Retrieved from https://www.kmu.gov.ua/storage/app/imported_content/news/ doc_248012532/UA_15-1\%20final.pdf [in Ukrainian].

7. Postanova Kabinetu Ministriv Ukrainy Pro Koordynatsiinu radu z pytan reformuvannia derzhavnoho upravlinnia vid 18 travnia 2016 r. No 335 [Resolution of the Cabinet of Ministers of Ukraine On the Coordination Council for Public Administration Reform of May 18, 2016 No 335]. (n.d.). zakon.rada.gov.ua. Retrieved from https://zakon.rada.gov.ua/laws/show/3352016-\%D0\%BF\#n33 [in Ukrainian].

8. Proiekt (upravlinnia proiektamy) [Project (project management)]. (n.d.). cutt.ly. Retrieved from https://cutt.ly/BQGrYYm [in Ukrainian].

9. Rada Yevropy. Detsentralizatsiia i reforma publichnoi administratsii v Ukraini [Council of Europe. Decentralization and reform of public administration in Ukraine]. (n.d.). www.slg-coe.org.ua. Retrieved from http:// www.slg-coe.org.ua/goal-and-objectives/ [in Ukrainian].

10. Reiestr prohram sektoralnoi biudzhetnoi pidtrymky Yevropeiskoho Soiuzu [Register of sectoral budget support programs of the European Union]. (n.d.). drive.google.com. Retrieved from https://drive.google.com/ file/d/1MXgCuPIV40LI8F2-p9aRPv8yCbX4FxkP/view [in Ukrainian].

11. Rozporiadzhennia Kabinetu Ministriv Ukrainy Pro vnesennia zmin do rozporiadzhen Kabinetu Ministriv Ukrainy vid 24 chervnia 2016 r. No 474 i vid 27 hrudnia 2017 r. No 1013 vid 18 hrudnia 2018 r. No 1102-r [Order of the Cabinet of Ministers of Ukraine On amendments to the orders of the Cabinet of Ministers of Ukraine of June 24, 2016 No 474 and December 27, 2017 No 1013 
of December 18, 2018 No 1102-r]. (n.d.). zakon.rada.gov.ua. Retrieved from https://zakon.rada.gov.ua/laws/show/1102-2018-\%D1\%80\#n14 [in Ukrainian].

12. Rozporiadzhennia Kabinetu Ministriv Ukrainy Deiaki pytannia reformuvannia derzhavnoho upravlinnia Ukrainy vid 21 lypnia 2021 r. No 831-r [Order of the Cabinet of Ministers of Ukraine Some issues of public administration reform in Ukraine of July 21, 2021 No 831-r]. (n.d.). zakon. rada.gov.ua. Retrieved from https://zakon.rada.gov.ua/laws/show/831-2021\%D1\%80\#Text [in Ukrainian].

13. Rozporiadzhennia Kabinetu Ministriv Ukrainy Deiaki pytannia reformuvannia derzhavnoho upravlinnia Ukrainy vid 24 chervnia 2016 r. No 474-r [Order of the Cabinet of Ministers of Ukraine Some issues of public administration reform in Ukraine of June 24, 2016 No 474-r]. (n.d.). zakon. rada.gov.ua. Retrieved from https://zakon.rada.gov.ua/laws/show/474-2016$\%$ D1\%80\#Text [in Ukrainian].

14. Ukraina. Otsinka systemy derzhavnoho upravlinnia 2006 r. [Ukraine. Estimation of the system of public administration in 2006]. (n.d.). www.center. gov.ua. Retrieved from http://www.center.gov.ua/attachments/article/11/Ukr Civil_service_Administration_Framework_General_Presentation_July05\%20 (1).ppt [in Ukrainian].

15. Council of Europe. Enhancing decentralisation and public administration reform in Ukraine. (n.d.). www.slg-coe.org.ua. Retrieved from http://www.slg-coe.org.ua/goal-and-objectives/?lang=en [in English].

16. SIGMA [SIGMA]. (n.d.). www.center.gov.ua. Retrieved from http:// www.center.gov.ua/pro-tsentr/proekti/sigma [in Ukrainian].

17. SWOT-analiz: (Treninh «Stratehichne planuvannia $\mathrm{v}$ okhoroni zdorovia na rivni hospitalnoho okruhu» Prohramy OON iz vidnovlennia ta rozbudovy myru) [SWOT-analysis: (Training «Strategic planning in health care at the hospital district level» of the UN Program for Reconstruction and Peacebuilding)]. (n.d.). www.ua.undp.org. Retrieved from https://www.ua.undp. org/content/dam/ukraine/docs/Donbas/RPP/P3-M2.pdf [in Ukrainian]. 


\section{Відомості про авторів / Information about the Authors}

Хаджирадсва Світлана Констянтинівна: Українська школа урядування: вул. Прорізна, 15 м. Київ, 01034, Україна.

Svitlana Khadzhyradieva: Ukrainian School of Government, 15, Prorizna str., Kiev, 01601, Ukraine.

ORCID. ORG./ 0000-0002-2256-2579

\section{E-mail: sententia.hsk@gmail.com}

Шевцова Олена Василівна: Київський національний університет імені Тараса Шевченка: вул. Володимирська, 64/13, Київ, 01601,Україна.

Jelena Shevtsova: Taras Shevchenko National University of Kyiv: Volodymyrska Street, 64/13, Kyiv, 01601, Ukraine.

ORCID.ORG/ 0000-0001-7311-6483

E-mail: shevtsovajelena@gmail.com 